\title{
Parents' Assistance In Instilling Independence Character in Learning from Home During The Covid-19 Pandemic
}

\author{
Ratna Purwanti ${ }^{*}$, Ahmad Suriansyah ${ }^{2}$, Wahdah Refia Rafianti ${ }^{3}$ \\ 123 Early Childhood Education Study Program, Universitas Lambung Mangkurat \\ Brigjen H. Hasan Basri Street, Kayu Tangi, Banjarmasin, Indonesia \\ *Author Correspondence. Email: ratna.purwanti@ulm.ac.id
}

Received: 28 June 2021; Revised: o5 November 2021; Accepted: 28 December 2021

\begin{abstract}
The training aims to provide knowledge to parents about instilling independence character while assisting their children in learning from home during the COVID-19 pandemic. The methods used in this training were lectures and discussions. The participants of this study were 27 parents of children of PAUD AT-Tibyan which is located in Central Banjarmasin. The training was conducted for two days in June 2021. It went well, and participants obtained knowledge of home learning assistance during the COVID-19 pandemic. The results of this activity can be used or modified by parents to assist their children in learning. A training program like this can be carried out regularly at schools with certain targets, for example, parents who need to be trained in assisting children in learning from home.
\end{abstract}

Keywords: independence, learning from home, COVID-19 pandemic, parental guidance

How to Cite: Purwanti, R, Suriansyah, A, Rafiantia, W.R(2021). Parents' Assistance In Instilling Independence Character in Learning from Home During The Covid-19 Pandemic. JPPM (Jurnal Pendidikan dan Pemberdayaan Masyarakat), 8(2), 203-211. doi: 10.21831/jppm.v8i2.41865

\section{Introduction}

Character education will be meaningless if it relies only on teachers. Parents need to help provide character education to children at home. One of the characters to be instilled in learning is independence. Aryani (2021) states that parents' communication with children during the COVID-19 pandemic is crucial. Moreover, Masruroh \& Munastiwi (2021) argue that online learning would be effective if it is fully supported by parents.

The values of character education will be meaningless if only teachers are responsible to teach them to children. Parents and the community should get involved in instilling the characters in order to build a character-based education system. One of the characters to be instilled is independence. This character will prevent children from relying heavily on others, and the most important thing is to grow their courage and motivation. According to Sahlan \& Prastyo (2017: 40), character values are important to gradually generate a global society possessing characters. The character values are taught in the main environment (parents) and the secondary environment (teachers).

Character plays a significant role in early childhood education. Teachers get involved with children in their daily lives at school, so they should be leading role 
models. Parents have a similar role to teachers when children are at home (the main environment). According to Wiyani (2013: 109), characters should be instilled in early childhood as children need to reach a better stage of maturity. Therefore, it is necessary for teachers to support the efforts in the school environment from an early age. Wibowo (2017: 107), states that early childhood education teachers are those who make various efforts in improving the quality and innovation of Education including the character of children, and one of their main tasks is giving direction in instilling character education.

Children will gain knowledge, skills, and values to maintain their existence in life from learning experiences (Wibowo, 2017: 97). One of the characters that must be owned by children is independence. According to Wiyani (2013: 89) independence is an ability that is adjusted with children's development, for example, learning. Children at an early age are able to carry out their developmental tasks well, hence they can already be considered as independent individuals.

However, as we know it, the world and Indonesia, in particular, are experiencing a COVID-19 pandemic that affects the education system in schools. To prevent the transmission of the virus, the revised copy of the Decree of four Ministers on face to face learning during the pandemic (No 03/KB/2020, No. 612/2020, No HK.01.08/Menkes/502/2020, No. 119/4536/SJ) regulates that educational units located in the orange and red zone areas based on data from the National Covid-19 Task Force, are prohibited from conducting face-to-face learning processes, and they should still conduct Learning from Home. During the COVID-19 pandemic, the government decided to carry out online learning or learning from home. One of the cities implementing the regulation is Banjarmasin. The regulation is implemented based on Circular Number: 80o/2878-Sekr/Dipendik, 2020.

In conducting online learning activities, teachers and parents normally face obstacles. Based on studies conducted by Kurniasari, A., Pribowo, F. S. P., \& Putra, D. A. (2020), surveys on the implementation of online learning show that this type of learning has poor effectiveness (48\%). In line with Fujiawati, F. S., Raharja, R. M., \& Iman, A. (2020) study, the problem with learning from home during the pandemic is parental support for the implementation of learning from home activities.

People need to pay more attention to this problem particularly in relation to the role of parents to accommodate children's potential. Independence is an aspect that must be achieved by kindergarten children in learning. Therefore, parents are required to understand and make the best use of this period during the learning from home period. The knowledge and experience gained by the children make them confident and sure about what they are doing. Parents are required to be more patient in providing various options and discussing with children about the activities that children should do when learning from home.

Pasya (2007:3-4) argues that parents are very influential on the children's psyche development, so they can build children's independence better. Moreover, Anwar and Ahmad (2007: 19) state that parents must optimally provide education to children so that children are able to have a dream and future. Therefore, parents as the first educators in children's environment or family are the most important parties in supporting children's success in the future. Parents should always care, love, and educate children well.

Sari, NY, \& Wisroni, W (2020) found that during the implementation of learning from home, parents can provide guidance so that when they get into the adolescent 
stage, they may succeed in learning. Parents should ensure that children live in a healthy environment. Moreover, they should accompany children in doing homework and school assignments, create a comfortable learning environment at home, maintain good communication with children, guide and motivate children in learning, and find out fun activities at home.

Agustin, M., Inten, DN, Permatasari, AN, \& Mulyani, D (2021) found that the strategy needed to teach kindergarten children should be in accordance with children's development, easy to be implemented by teachers at home, meaningful, and fun. In addition, Yulianingsih, W., Suhanadji, S., Nugroho, R., \& Mustakim, M (2020) point out that parents have a role in teaching children, fulfilling children's needs, giving spiritual knowledge, supervising, motivating children, and providing children with learning facilities. Learning assistance for children can be seen from the way parents help their children solve problems, explain the material that children don't understand, and respond well to all online learning from school. A study conducted by Fransiska, F (2016) found that parents' involvement is the most important party, while teachers' role in learning is the second one. Malik, H. K., \& Sumarno, S. (2016) state that parents' concern for children's education is important.

It can be concluded that building children's independence cannot be separated from the parent's role in the family. Parents who have sufficient knowledge about the importance of values, attitudes, and skills in creating good family conditions will greatly affect the development of their children, including independent behavior. Habituation that parents do during childhood will make children get accustomed to being independent when they grow up. It is important to realize that during the COVID-19 pandemic, parents should educate and know their roles. Therefore, they should not only provide sufficient materials for learning but also spend time to assist their children during learning.

Knowledge about parental guidance is needed to instill children's independence during the learning from home period in the COVID-19 pandemic. Therefore, parental guidance is something that must be done optimally, as it is necessary to assist, train, and provide knowledge to parents in instilling the character.

\section{Method}

The community service program was carried out at PAUD/Early Childhood Education At-tibyan which is located in Central Banjarmasin. Following the health protocol, the researchers collected relevant information about parents' assistance in learning through focus group discussion. The materials prepared were characteristics of early childhood, children characters, and parental guidance in instilling independence value during the Covid-19 Pandemic.

The method used in the program was lecture. The researchers presented materials on parents' guidance in instilling independence value. Moreover, in the focus group discussion, parents shared their problems during learning from home. Partners' role is very important in this activity because they provided a place, facilities, such as LCD projector and speakers to conduct the program.

The target audience for this activity was parents of Groups A and B of the PAUD Terpadu At-tibyan Banjarmasin. The school is located on Jalan Dahlia, Central Banjarmasin. As many as 30 parents were divided into two groups (shifts) to reduce 
JPPM (Jurnal Pendidikan dan Pemberdayaan Masyarakat), 8 (2), 2021 - 206

Ratna Purwanti, Ahmad Suriansyah, Wahdah Refia Rafianti

crowds on the first and second days. This training was expected to provide knowledge and understanding to parents in guiding children during learning from home.

\section{Result and Discussion}

From the results of this training activity, it can be concluded that the implementation of parental assistance activities in instilling independence value during the Covid-19 Pandemic at PAUD At-Tibyan went well. The participants looked very enthusiastic, and the training activities went well. The training materials were well understood by the participants, as they seemed to have more knowledge of home learning assistance by instilling independence value. Thus, it is assumed that such training activities can be carried out on a regular basis either in the same school or in different schools. Parental guidance mentoring training activities in instilling independence value during the Covid-19 pandemic include preparation, implementation, and evaluation stages. The stages are further explained as follows.

\section{1) Preparation Stage}

In the preparation stage, the training team discussed with the principal and the head of the PAUD AT-Tibyan Foundation to discuss the time, place, and facilities needed for the activity. Then, they agreed that it would be held on June 4 and 5, 2021.

The next step taken by the Team in the preparation stage was making a permission letter. The team also prepared PowerPoint slides that contained materials on how to instill independence value in children during learning from home activities. Materials about characteristics of children at an early age and parental guidance in instilling independence were also presented.

2) Implementation Stage

In the implementation stage, at first, the participants registered at the front desk.

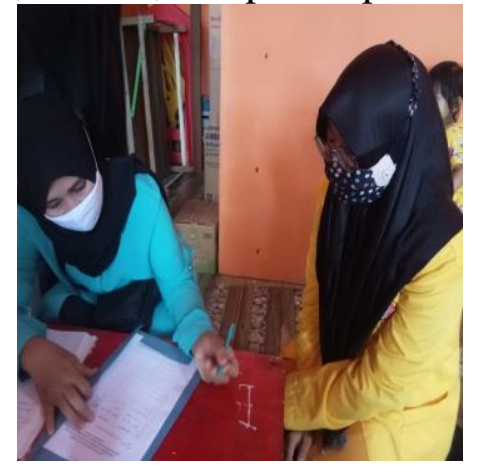

Figure 1: Participant Registration

The next is opening. The Head of PAUD At-Tibyan introduced the team and sang the Indonesia Raya song. The first material presented was the introduction. It contained materials on children's characteristics. Children at the early age are unique, egocentric, active, energetic, curious, and enthusiastic for many things, adventurous, spontaneous, always happy, and full of imagination. Moreover, they are passionate to learn, learn a lot from experience, and show more interest in friends. However, they are easily frustrated, have a lack of consideration in doing things, have a short attention span. After the break, 
JPPM (Jurnal Pendidikan dan Pemberdayaan Masyarakat), 8 (2), 2021 - 207

Ratna Purwanti, Ahmad Suriansyah, Wahdah Refia Rafianti

the team presented the material on early childhood characters and then proceeded with a discussion session (figure 2 ).

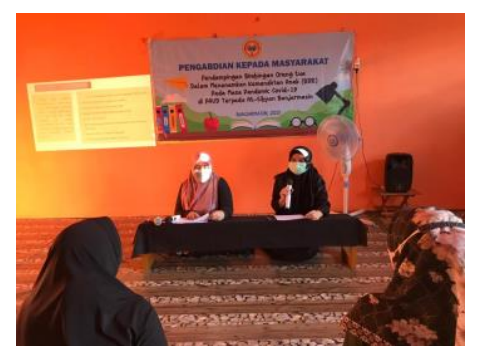

Figure 2: Presentation of Materials I and II

On day 2, the material presented was about parents' role in instilling independence value during learning from home situations. How the presentation is done is shown in Figure 4 below.

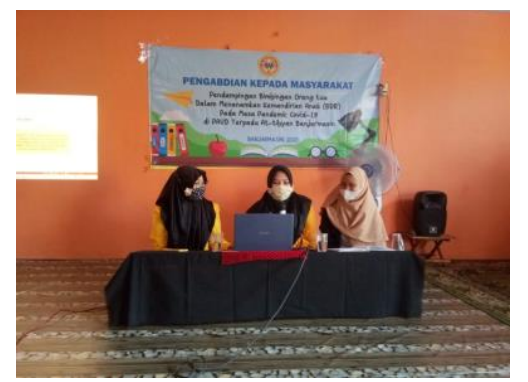

3) Evaluation Stage

Figure 4: Presentation of Material III

After participants obtained knowledge about parental guidance in instilling independence value during the COVID-19 Pandemic from all speakers, questionnaires were distributed. Each parent was asked to fill in the questionnaires in accordance with the knowledge provided during the training. The result of the survey is presented in Table 1 below.

Table 1. The Result of Survey on 27 Participants after Training

\begin{tabular}{|c|c|c|c|c|}
\hline \multirow{4}{*}{ No } & \multirow{4}{*}{$\frac{\text { Item }}{\text { (After training) }}$} & \multirow{3}{*}{\multicolumn{2}{|c|}{$\begin{array}{c}\text { The number } \\
\text { of answers } \\
\text { from } \\
\text { participants }\end{array}$}} & \multirow{4}{*}{$\begin{array}{c}\% \\
\text { Level of } \\
\text { understanding }\end{array}$} \\
\hline & & & & \\
\hline & & & & \\
\hline & & Yes & No & \\
\hline \multirow[t]{2}{*}{1} & \multirow{2}{*}{$\begin{array}{l}\text { Do you know the importance of character } \\
\text { education in learning from home? }\end{array}$} & & & \\
\hline & & 27 & - & $100 \%$ \\
\hline \multirow[t]{2}{*}{2} & \multirow{2}{*}{$\begin{array}{l}\text { Do you know the importance of your role in } \\
\text { instilling independence character? }\end{array}$} & & & \\
\hline & & 23 & 4 & $62.1 \%$ \\
\hline \multirow[t]{2}{*}{3} & \multirow{2}{*}{$\begin{array}{l}\text { Do you know the importance of spending time } \\
\text { with children during learning from home? }\end{array}$} & & & \\
\hline & & 27 & - & $100 \%$ \\
\hline \multirow[t]{2}{*}{4} & \multirow{2}{*}{$\begin{array}{l}\text { Are you able to identify your children's } \\
\text { characters? }\end{array}$} & & & \\
\hline & & 25 & 2 & $92.5 \%$ \\
\hline \multirow[t]{2}{*}{5} & \multirow{2}{*}{$\begin{array}{l}\text { Are you able to identify the characteristics of } \\
\text { independent children? }\end{array}$} & & & \\
\hline & & 24 & 3 & $88.8 \%$ \\
\hline \multirow[t]{2}{*}{6} & \multirow{2}{*}{$\begin{array}{l}\text { Are you able to design activities to set an } \\
\text { example for children at home during learning } \\
\text { from home? }\end{array}$} & & & \\
\hline & & 27 & - & $100 \%$ \\
\hline 7 & $\begin{array}{l}\text { Are you able to design habituation activities in } \\
\text { the family to train children to get used to doing }\end{array}$ & & & \\
\hline
\end{tabular}

Copyright @ 2021, JPPM, ISSN 2355-1615 (print), ISSN 2477-2992 (online) 
JPPM (Jurnal Pendidikan dan Pemberdayaan Masyarakat), 8 (2), 2021 - 208

Ratna Purwanti, Ahmad Suriansyah, Wahdah Refia Rafianti

\begin{tabular}{|c|c|c|c|c|}
\hline & $\begin{array}{l}\text { things independently during learning from } \\
\text { home? }\end{array}$ & 27 & - & $100 \%$ \\
\hline \multirow[t]{2}{*}{8} & \multirow{2}{*}{$\begin{array}{l}\text { Are you able to give sincere praise to appreciate } \\
\text { your children during learning from home? }\end{array}$} & & & \\
\hline & & 27 & - & $100 \%$ \\
\hline \multirow[t]{2}{*}{9} & \multirow{2}{*}{$\begin{array}{l}\text { Are you able to provide supports to your } \\
\text { children during learning from home? }\end{array}$} & & & \\
\hline & & 27 & - & $100 \%$ \\
\hline \multirow[t]{2}{*}{10} & \multirow{2}{*}{$\begin{array}{l}\text { Are you able to communicate well with your } \\
\text { children during learning from home? }\end{array}$} & & & \\
\hline & & 24 & 3 & $88.8 \%$ \\
\hline \multirow[t]{2}{*}{11} & \multirow{2}{*}{$\begin{array}{l}\text { Are you able to offer choices to your children } \\
\text { during learning from home? }\end{array}$} & & & \\
\hline & & 26 & 1 & $96.2 \%$ \\
\hline \multirow[t]{2}{*}{12} & \multirow{2}{*}{$\begin{array}{l}\text { Are you able to help children to solve problems } \\
\text { in order to increase their abilities and make } \\
\text { them responsible for themselves? }\end{array}$} & & & \\
\hline & & 25 & 2 & $92.5 \%$ \\
\hline
\end{tabular}

After the evaluation activities are completed, the next step is the closing activities. The implementation of parental guidance training activities in instilling independence value during the Covid 19 Pandemic at PAUD At-Tibyan went well. This can be seen from how enthusiastic the participants were during the training activities. The parents asked about the topic presented and they told the team about the suitable assistance provided to children after they listened to the presentation.

Children at the early age are individuals undergoing very rapid growth and development process. They are in a very valuable age range compared to later ages because the development of intelligence is extraordinary. It is when the golden age occurs, and the stimulation of all aspects of development plays an important role in further development. This age is a unique phase of life. It has its own characteristics according to the stages and includes some other stages, namely growth, development, maturation, and refinement, both in physical and spiritual aspects which lasts a lifetime, gradually and continuously (Mulyasa, 2012:16).

According to Wiyani (2012: 32), children at the early age are those under six years of age or the moment that determines the character and personality development. Early childhood is the age when children experience rapid growth and development. It is the most important and fundamental moment in the entire span of growth and development of human life. This period fundamental period plays an important role in children's lives in the future. Fadlillah (2012:57) states that children at the early age are unique, egocentric, active, energetic, curious, and enthusiastic for many things, adventurous, spontaneous, always happy, and full of imagination. Moreover, they are passionate to learn, learn a lot from experience, and show more interest in friends. However, they are easily frustrated, have lack consideration in doing things, have short attention span.

According to Fadlillah (2012: 58), early age is a period of development and growth that will determine children's development in the future or in adulthood. Early childhood is a period when children have various characteristics when behaving. All forms of activity or behavior shown by a child are basically nature. Because early childhood is a period of development and growth that will shape the personality as an adult. Early childhood has unique and rapid developmental characteristics. The development experienced by children is greatly influenced by how they grow. If the 
children grow well, in general, they will have good development. It can be concluded that children are unique individuals who have a certain personality. However, children at the early age, especially kindergarten students, have characteristics that are in accordance with the stages of development.

It can be concluded that this training activity can improve parents' knowledge about home learning assistance during the COVID-19 pandemic by instilling independence value in children. Parents are very influential in providing good guidance at home, especially instilling good characters or values. Because the children are at the golden age, they need to be provided with basic knowledge, one of which is independent value. The effort of instilling the value is through learning assistance because parents play an important role in instilling the value when children learn at home.

According to Wiyani (2015), independence is the ability to make choices and accept the consequences that come with them. Independence in children manifests when they use their own minds in making decisions, for example, choosing the learning equipment that he wants to use, choosing a playmate, and things that are relatively more complicated and include more serious consequences. Individual independence is reflected in the way of thinking and behaving, making decisions, directing and developing themselves, and adapting constructively to the norms in their environment. Independence character is reflected in some aspects, namely (a) having confidence in oneself, (b) having high intrinsic motivation, (c) being able and daring to make their own choices, (d) being creative and innovative, (e) being responsible for accepting the consequences of their choices, and (f) adapting to the environment, and (g) not being dependent on others.

Children with independence character are those who dare to make their own choices, have good self-confidence, and easily adapt themselves with both their friends and new environment. Wiyani (2015:33-34) points out that independent children have confidence, have high intrinsic motivation, are able and dare to make their own choices, are creative and innovative, are responsible for consequences that accompany their choices, are able to adapt in the environment, and are not dependent on others. As parents play an important role in developing and strengthening children's character, one of which is independence, they need to possess sufficient knowledge and experiences.

Guidance is a process of helping individuals to understand themselves and their world. Parental guidance is a continuous effort made by parents in the educational process (Wiyani, 2015: 40). Tridhonanto (2014) argues that parenting is an overall interaction between parents and children where parents provide encouragement for children by changing behavior, knowledge, and values that are considered the most appropriate so that children can be independent, confident, friendly, and have an orientation to success. Parents better provide the best parenting style that is able to create a good family condition that affects the children.

The education provided by parents to their children when they are young serves as the main foundation for their education and life in the future. Independence is a result of habituation and experiences. Therefore, children will not understand and know how to develop themselves or their independence without guidance, habituation, and examples. Therefore, it is very important for parents to be able to encourage and build independent character during the learning from home period. Studies conducted by Kurniati, E., Alfaeni, DKN, \& Andriani, F. (2020) found that the parents have roles as mentors, educators, protectors, and supervisors. They need to assist children in learning, 
do activities with children at home, advise, and motivate children to learn at home. Moreover, Cahyati, N., \& Kusumah, R. (2020) found that parents have crucial roles in the learning from home process, hence they need to improve their relationship with their children to evaluate the children's cognitive development in learning.

Parental guidance/assistance to develop children's independence according to Anwar and Ahmad (2007: 27) can be done through habituation, giving examples, giving sincere praise, providing support, maintaining communication well, giving choices, and helping in problem-solving. Therefore, it can be concluded that parents must provide optimum guidance to children so that the desired goals are achieved optimally. That is why the training done in this program is important.

After the training was completed, participants were expected to obtain knowledge to instill independence value in children during the learning from home period during the Covid-19 Pandemic through some activities. First, habituation, parents need to create good habits in the family for children. They should train children to get used to doing things independently without having to be helped continuously. Second, parents should give an example by showing good attitudes and language as children tend to imitate what the parents do instead of doing what they are told to do. Third, parents should give honest praise and appreciation when the children succeed in doing something or completing certain tasks. The parents should also praise the children when they fail to do something. Fourth, parents should always support the children as parental support and appreciation are needed. Children feel appreciated when they do something by themselves. Fifth, parents should maintain good communication with children because it shows that parents care about what the children go through. Sixth, parents should offer choices to children, so children get used to accepting consequences on what they choose. These choices and consequences may help develop children optimally. At last, as children and parents have different problems, parents need to help children solve problems, so they will develop their sense of responsibility.

\section{Conclusion}

The training for parents in assisting children to learn at home went well. It is shown from how enthusiastic the parents were during the process. The materials presented could be understood well as the parents now improve the knowledge of assisting children and instill independent character during learning from home. This training may be conducted regularly by the school or other schools

\section{References}

Anwar dan Ahmad, Arsyad. (2007). Pendidikan Anak Dini Usia Panduan Praktis bagi Ibu dan Colon Ibu. Bandung. Alfabeta.

Agustin, M., Inten, D. N., Permatasari, A. N., \& Mulyani, D. (2021). Strategi Guru PAUD dalam Mengembangkan Kecerdasan Interpersonal Anak Usia Dini di Saat Belajar dari Rumah. Jurnal Obsesi: Jurnal Pendidikan Anak Usia Dini, 5(2), 1997-2007.

Aryani, Eka. (2021). Communication of Parents and Early Childhood to Build Confidence in The Pandemic Covid-19. JPPM (Jurnal Pendidikan dan Pemberdayaan Masyarakat), 8(1), 6775 .

Cahyati, N., \& Kusumah, R. (2020). Peran Orang Tua Dalam Menerapkan Pembelajaran Di Rumah Saat Pandemi Covid 19. Jurnal Golden Age, 4(o1), 152-159. 
JPPM (Jurnal Pendidikan dan Pemberdayaan Masyarakat), 8 (2), 2021 - 211

Ratna Purwanti, Ahmad Suriansyah, Wahdah Refia Rafianti

Fadlillah, Muhammad. (2012). Desain Pembelajaran PAUD, Panduan untuk Pendidik, Mahasiswa, dan Pengelola Pendidikan Anak Usia Dini. Yogyakarta: Ar-Ruzz Media.

Fransiska, F. (2016). Pendidikan multikultural di TK Mutiara Persada Soragan Yogyakarta. JPPM (Jurnal Pendidikan dan Pemberdayaan Masyarakat), 3(2), 152-164.

Fujiawati, F. S., Raharja, R. M., \& Iman, A. (2020, November). Pemanfaatan Teknologi Untuk Pendidikan Anak Usia Dini Di Masa Pandemi Covid-19. In Prosiding Seminar Nasional Pendidikan FKIP (Vol. 3, No. 1, pp. 120-125).

Kurniati, E., Alfaeni, D. K. N., \& Andriani, F. (2020). Analisis Peran Orang Tua dalam Mendampingi Anak di Masa Pandemi Covid-19. Jurnal Obsesi: Jurnal Pendidikan Anak Usia Dini, 5(1), 241-256.

Kurniasari, A., Pribowo, F. S. P., \& Putra, D. A. (2020). Analisis Efektivitas Pelaksanaan Belajar Dari Rumah (Bdr) Selama Pandemi Covid-19. Jurnal Review Pendidikan Dasar: Jurnal Kajian Pendidikan Dan Hasil Temuan, 6(3), 246-253.

Malik, H. K., \& Sumarno, S. (2016). Kepedulian orang tua terhadap pendidikan anak untuk menyelesaikan program wajar 9 tahun. JPPM (Jurnal Pendidikan dan Pemberdayaan Masyarakat), 3(1), 38-47.

Masruroh, Lely \& Munastiwi, Tiwi. (2021). Portrait Analysis of Early Childhood Education in Cities and Villages: The COVID-19 Pandemic Era. JPPM (Jurnal Pendidikan dan Pemberdayaan Masyarakat), 8(1), 58-66.

Mulyasa, H., E. (2012). Manajemen PAUD. Bandung: PT. Remaja Rosdakarya.

Pasya, H. S. (2007). Bimbingan Mendidik Anak Sejak kecil hingga Dewasa. Bandung. Raska Dinika Pustaka.

Sari, N. Y., \& Wisroni, W. (2020). The Urgency of Parental Guidance for Youth Education in the Belajar Dari Rumah (BDR) Era. SPEKTRUM: Jurnal Pendidikan Luar Sekolah (PLS), 8(3), 309-321.

Salinan Revisi SKB 4 Menteri PTM. (2020). NOMORo3/KB/2020, NOMOR 612 TAHUN 2020, NOMOR HK.o1.08/Menkes/502/2020, NOMOR 119/4536/SJ Tentang Panduan Penyelenggaraan Pembelajaran Pada Tahun Ajaran 2020/2021dan Tahun Akademik 2020/2021 di Masa Pandemi Coronavirus Disease2019 (Covid-19).।

Surat Edaran Nomor: 80o/2878-Sekr/Dipendik (2020). Tentang Kebijakan Bidang Pendidikan Tahun Pelajaran 2020/2021 Di Kota Banjarmasin.

Susanto, Ahmad. (2017). Pendidikan Anak Usia Dini Konsep dan Teori. Jakarta: Bumi Aksara.

Tridhonanto, Al. (2014). Mengembangkan pola asuh demokratis. Jakarta: PT Elex Media Komputindo.

Wiyani, N. A. (2012). Bina Karakter Anak Usia Dini: PAnduan Orang Tua dan Guru Dalam Membentuk kemandirian dan kedisiplinan Anak Usia Dini. Ar-ruzz media.

Wiyani, Novan Ardy. (2015). Bina karakter Usia dini. Ar-ruzz Media. 